\title{
The Evaluation of the Perceptibility and Accessibility: The Case of Gaziantep
}

\author{
Ahmet Salih Günaydın ${ }^{1 \odot}$, Murat Yücekaya $2 \odot$ \\ ${ }^{1}$ Asst. Prof. Dr. Inonu University, Faculty of Fine Arts and Design, Department of Landscape Architecture 44280, \\ Malatya/Turkey E-mail: ahmet.gunaydin@inonu.edu.tr \\ ${ }^{2}$ Dr., Nevșehir Hacı Bektaș Veli University, Faculty of Engineering and Architecture, Department of Landscape Architecture, \\ Nevşehir/Turkey (Principal contact for editorial correspondence.) E-mail: muratyucekaya@nevsehir.edu.tr
}

\begin{abstract} Purpose

The study focuses on accessibility to green spaces. In this context, the study aims to determine the accessibility of green areas in metric and topological terms, and to examine and discuss their social and functional contributions.
\end{abstract}

\section{Design/Methodology/Approach}

The study was designed in 5 stages. In the first phase of the study, a convex area map was formed within the limit of accessibility based on the literature research. In the second phase, the axial map was created. In the third phase, the integration map was used to determine the visual perceptibility of the green areas within the study area. The Depthmap software was used in analysis and creation of the maps. In the fourth phase, all findings obtained are explained and discussed with detailed graphics and maps. In the last phase of the study, some suggestions regarding the study area and general spatial planning approach were developed in the light of scientific principles in order to ensure urban green areas' contribution to the city and residents

\section{Findings}

All analysis results were evaluated in a holistic manner and the spatial relationship between residential areas and green areas in the study area was found to be weak and the perception of green areas was moderate.

\section{Research Limitations/Implications}

Further studies should be conducted to evaluate the accessibility of several parks of different sizes with other various methods. In the study, accessibility values were obtained with the Space syntax method. These values can be compared to each other with other analysis methods.

\section{Practical Implications}

This analysis will enable issues such as park locations in city plans, their size, and intervals to be more professionally handled. Thus, living space conditions and indirectly cities will be improved. As a result, urban life quality will flourish.

\section{Social Implications}

Urban green spaces are important components of the city in that they contribute positively to urban residents in terms of environmental, social, economic etc. aspects. For this reason, it is extremely important for people to have easy access to parks for socialization purposes.

\section{Originality/Value}

It is considered that examining accessibility with the space syntax method, unlike other conventional methods, adds an important value to the study.

Keywords : Accessibility, perceptibility, space syntax, urban green space. 


\section{INTRODUCTION}

Liveable cities are spaces which are accessible, usable, shared and integrated where all individuals and social groups freely and comfortably come together. Legible and accessible urban spaces for everyone are indispensable to participate in social life (Afacan, 2015). $\mathrm{n}$ many developing cities, unplanned and irregular settlements have led an increase in social and spatial inequality, resource consumption and environmental disruption (Leichenko \& Solecki, 2008). In order to prevent this increase and to contribute to the solution of urban problems, it is very important to accurately understand and manage urban pattern created by bringing the streets, parcels, buildings, and the main physical components of the city together. The urban pattern occurs as a result of the different actors shaping the space at different scales, with different objectives, requirements and motivations (Ünlü, 2018). The main purpose behind this formation is to facilitate social life by creating interconnected holistic spaces.

As being among the most important places of social life, urban green areas are an important indicator of a quality life (Wright et al., 2012) and they are also considered as one of the most important elements of urban planning. Green areas in the cities are important areas for their role in reducing the negative effects of these problems and increasing the quality of urban life. In the urban context, green areas consist of parks, urban forests, natural reserves, green corridors, sports fields and other informal green areas (La Rosa \& Privitera, 2013). These spaces provide significant benefits to urban residents, such as improving air quality, increasing urban environmental quality (Bolund ve Hunhammar, 1999; Fan et al., 2017), recreation and relaxation by contacting with nature, contributing positively to mental and physical health ( Barrera et al.. 2016). Considering urban green areas' benefits for urban residents, it is clearly understood that these areas are an important indicator for improving life quality and that the adequacy and accessibility of these areas are of great importance (Wright Wendel et al., 2012). Accessibility to public green spaces is one of the most discussed issues in sustainable urban planning, especially in environmental justice and public health (La Rosa, 2014). The main reason for this is the increased stress on the definition of the benefits of urban green areas today (Ward Thompson, 2011).

Accessibility is defined as the behaviour of people within structure of urban area from local to global (Mahdzar, 2008). Accessibility is the ease of access for moving towards a destination (Department of the Environment, 1994). Access to green areas is an important tool for improving equality and social justice within urban areas. Studies on green space accessibility are often based on metric measurements, ignoring topological measurement (Fan et al., 2017; Koohsari et al., 2018; La Rosa, 2014; Nicholls, 2001; Stessens, Khan, Huysmans, \& Canters, 2017; Van Herzele \& Wiedemann, 2003). ). In this study, both 
topological and metric measurements were used to determine the accessibility levels to green areas and to make comparisons between them. Topology is the connection pattern of a particular space. The topological measurement of an axle refers to the relationship of any axle in the system with all other axles. In other words, the topological distance for public open spaces calculates how many turns a person should take on the streets to reach any open space (Koohsari et al., 2015). People perceive urban spaces topologically and geometrically and act accordingly (Hillier \& Iida, 2005). Topological features are more effective than metric features in formation of urban spaces such as streets, that is, in understanding their configuration (Penn, 2003). In other words, metric distances are not fully sufficient to explain accessibility (Koohsari et al., 2013). For example, two people located at the same metric distance to a public space, might be at a topologically different distance (Figure 1).

Figure 1. Metric distances are the same, topological distances are different (Koohsari et al., 2013)

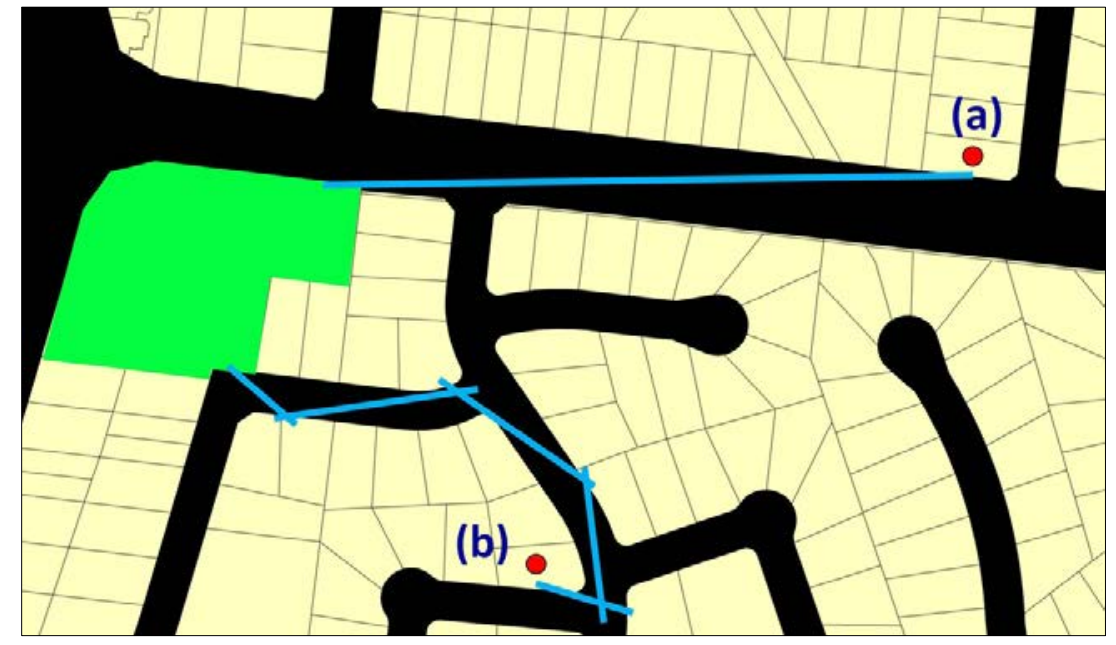

Another important feature as important as access to urban green areas is the visual perceptibility and quality of green areas. Green areas encountered visually in complex city structure were proven by previous studies to have had a large positive impact on human soul and physical health (Sanesi et al., 2006; Ekkel \& de Vries, 2017; Francis, 2010; Koohsari et al., 2018). In addition, it provides a positive contribution to human psychology by providing a balance between human and environment (Gül \& Küçük, 2001). Above all, it provides residents an opportunity to observe the nature and natural beauties with their continuously changing appearance in different seasons and to integrate with nature (Önder \& Polat, 2012). Therefore, the perceptibility of green areas in this complex structure is quite an important issue.

The Space Syntax method, developed by Bill Hillier and his team, has recently been widely used to understand the configuration of urban spaces and to determine the possible effects of these properties on human movements (B Hillier et al., 1993; Bill Hillier, 2001; Asami et al., 2001; Bill Hillier \& Iida, 2005; Baran et al., 2008; Özbil et al., 2011; 
Koohsari et al., 2013; Topçu, 2019). Space syntax analysis shows the potential accessibility and perceptibility (visibility) of streets and alleyways that form a street network (Hillier et al., 1993). The results of space syntax measurements are not only related to people's behavior but also to their perceptions in critical levels (Alalouch et al., 2009). Many studies have shown a strong correlation between integration value and usage (B Hillier et al., 1993; Bill Hillier \& Iida, 2005; Özer \& Kubat, 2007; Baran et al., 2008; Özbil et al., 2011). Thus, the green areas located on streets with high integrity value will have more perceptibility than the green areas on the streets with low integrity value.

Informed by the above-mentioned literature research, this study was carried out in the Istiklal Park and in its immediate vicinity in Şahinbey region, the central district of Gaziantep Metropolitan Municipality. In the study conducted at neighborhood level, an axial map was primarily created within the accessibility limits determined by the literature. Later, both metric and topological accessibility levels were determined and compared based on this map. In the last phase of the study, the perceptibility of the green area was evaluated.

\section{METHODOLOGY}

\section{Research case}

The study was conducted in Gaziantep city as the eighth most populous city in Turkey which slowly becomes a cosmopolitan city due to its high migration rates from Syria along with East and Southeastern regions. It dealt with the Istiklal Park and its vicinity in Istiklal Neighborhood located in Şahinbey, one of the central districts of the city (Figure 2). Previous studies have been called upon to determine the accessibility limits and size of the green area. Competence and accessibility standards for the green areas in different scales in the city have been specified in many studies (Altunkasa, 2004; Jia 2001 (Gupta, Roy, Luthra, Maithani, \& Mahavir, 2016); Nicholls, 2001 (NRPA); Van Herzele \& Wiedemann, 2003) (Table 1). For example, Altunkasa (2004) proposed an accessibility distance of $800 \mathrm{~m}$ to neighborhood parks and area of 40 ha; Herzele and Wiedemann (2003) determined the accessibility at the same level as $400 \mathrm{~m}$ and the area as 1 ha. The NRPA suggested an accessibility distance of $800 \mathrm{~m}$ with an area of 2.8-4.1 ha. This study utilized the accessibility standards $(400 \mathrm{~m})$ and green area and park size values (min. 1ha) as proposed in Herzele and Wiedemann (2003). 
Figure 2. Geographical location of the study area

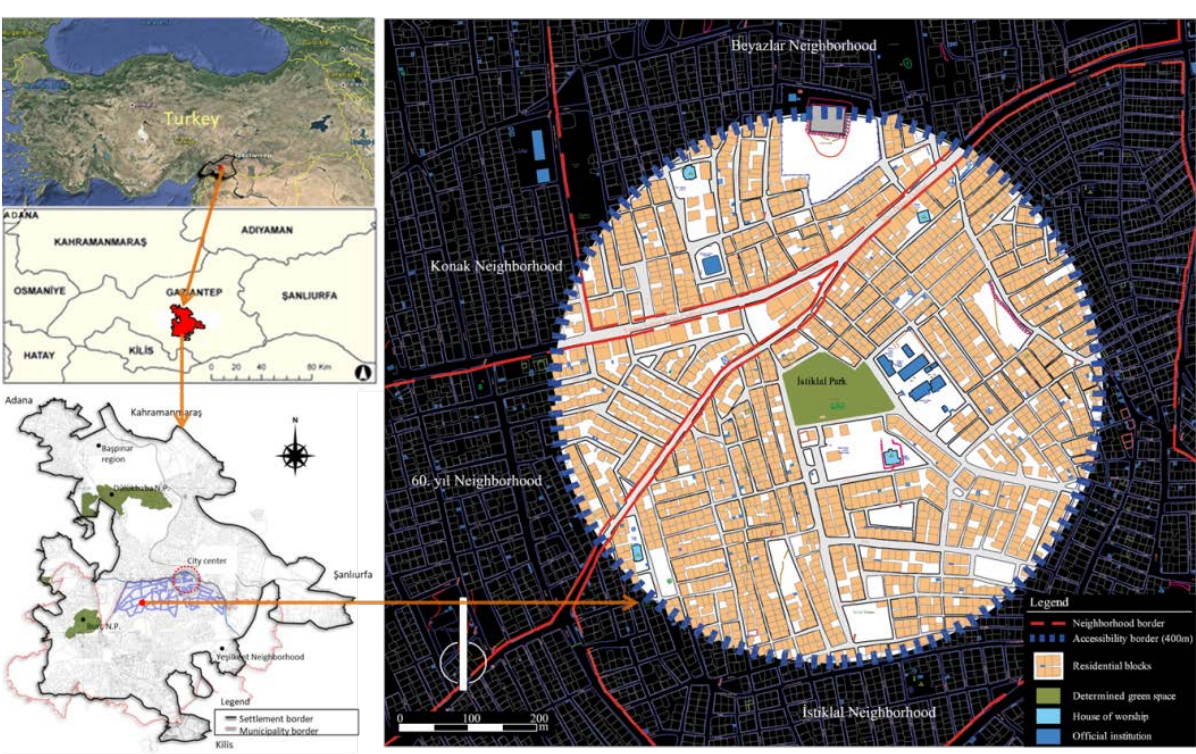

Table 1. Competence and accessibility measures for urban green areas

\begin{tabular}{|c|c|c|c|c|}
\hline \multirow[t]{3}{*}{$\begin{array}{ll}\text { Green } & \text { Field } \\
\text { Type } & \end{array}$} & $\begin{array}{l}\text { Altunkasa } \\
\text { (2004) }\end{array}$ & $\begin{array}{l}\text { Herzele and } \\
\text { Wiedemann } \\
(2003)\end{array}$ & NRPA & Jia (2001) \\
\hline & Size (ha) & Size (ha) & Size (ha) & Size (ha) \\
\hline & $\begin{array}{l}\text { Accessibility } \\
\text { (m) }\end{array}$ & $\begin{array}{l}\text { Accessibility } \\
\text { (m) }\end{array}$ & $\begin{array}{l}\text { Accessibility } \\
\text { (m) }\end{array}$ & $\begin{array}{l}\text { Accessibility } \\
\text { (m) }\end{array}$ \\
\hline \multirow{2}{*}{$\begin{array}{l}\text { Children's } \\
\text { playground }\end{array}$} & 30 & - & $0,4-2$ & $0.02-0.04$ \\
\hline & 400 & - & 400 & $300-400$ \\
\hline \multirow[t]{2}{*}{ Play ground } & 80 & - & & \\
\hline & 400 & - & & \\
\hline \multirow{2}{*}{$\begin{array}{l}\text { Neighborhood } \\
\text { Park }\end{array}$} & 40 & 1 & $2,8-4,1$ & $2-8$ \\
\hline & 800 & 400 & 800 & $400-800$ \\
\hline \multirow[t]{2}{*}{ Quarter Park } & 160 & $5-10$ & $8,1-20,3$ & $8-40$ \\
\hline & 800 & 800 & $800-4000$ & $800-5000$ \\
\hline \multirow[t]{2}{*}{ City Park } & 1000 & $10-30$ & - & $>40$ \\
\hline & 1200 & 1600 & - & - \\
\hline \multirow{2}{*}{$\begin{array}{l}\text { Metropole } \\
\text { park }\end{array}$} & 5000 & 60 & - & - \\
\hline & 2400 & 3200 & - & - \\
\hline \multirow[t]{2}{*}{ Regional Park } & 40000 & - & - & $>100$ \\
\hline & - & - & - & \\
\hline \multirow[t]{2}{*}{ City Forest } & - & $\begin{array}{l}\text { Small } \\
\text { settlement> } \\
200 \\
\text { Big city> } 300\end{array}$ & - & \\
\hline & - & 5000 & - & \\
\hline
\end{tabular}

The study consists of data collection, analysis-synthesis and evaluation phases based on the studies and the standards set forth previously. At the data collection stage, the current map of Şahinbey at the scale of 1/1000, 1/5000 scale zoning plan, 2018 address based census (TÜİK, 2018) and field surveys were used as main tools. In addition, Depthmap 10, Autocad 2016 and Arcgis 10.2 software were used to determine accessibility and perceptibility levels. 


\section{Space syntax}

Space syntax is a set of techniques that help define the properties of spatial configuration and reveal their connection with social life in urban morphological research. This method uses graphic theory to describe and digitize the extent to which spaces are accessible, readable and perceptible by analyzing different scales from residential to urban. Likewise, the method is a useful tool for comparing spatial features. It helps us to understand how urban space is related to social, economic, and cognitive factors and their effects on shaping the space(Hillier et al., 2007; Nes \& Yamu, 2017). This method offers a range of analytical techniques to explore the link between city form and city function and to represent and analyse urban topology (Lebendiger \& Lerman, 2019). This technique is an important tool for the evaluation and development of design policies and urban planning. The main parameter of this theoretical framework is to define the relationship between urban space and social forces by revealing the effect of spatial order on social life(Fladd, 2017; Hillier \& Hanson, 1984). The Space syntax method, which was developed by Hillier and his team in the 1980s at College London to understand and analyse the complexity of spatial arrangement in urban morphology and its impact on urban life, explains the objectivity of space according to two assumptions. The first is that space is closely linked to human activity, and the second is that space has a fundamentally configurative structure (Hillier \& Hanson, 1984; Hanson \& Hillier, 1987; Hillier, 2008).

Space syntax tries to explain the relative importance of each street segment by two variables that are basically based on graph theory: Integration and Choice. It is the value used to understand the movement in the integration system and the depths of the areas that make up the system relative to each other (Mustafa \& Rafeeq, 2019). This value is of great importance in defining how both vehicle and pedestrian movements function within the urban system and in understanding how often public spaces are used (Hillier, 2007). Choice, The extent to which a space can be a part of the shortest route to a destination (Hillier et al., 1987). Axial maps, which enable us to perform basic analyses of the space syntax method such as integration and choice, consist of lines defining the longest lines of view and movement that represent the structure of the public space (Karimi, 2012). Each line provides a link between two nodes. These connections consist of the longest and shortest lines representing the structure of the public space. The map formed by these lines representing the urban space is called an axial map (Figure 3). This axis map is a representation of the spatial model to be analysed. The advantage of this model is that it creates a spatial network model that defines how the network is perceived by people (visibility) and how it passes through (movement). The degree to which a public space is centrally located can affect many features such as its accessibility and perceptibility. The relationship between how the space 
is structured and how it is used by people reveals an analysis that can be directly used and interpreted in the urban design process (Karimi, 2012).

Figure 3. Axial Map (Hillier \& Hanson, 1984)

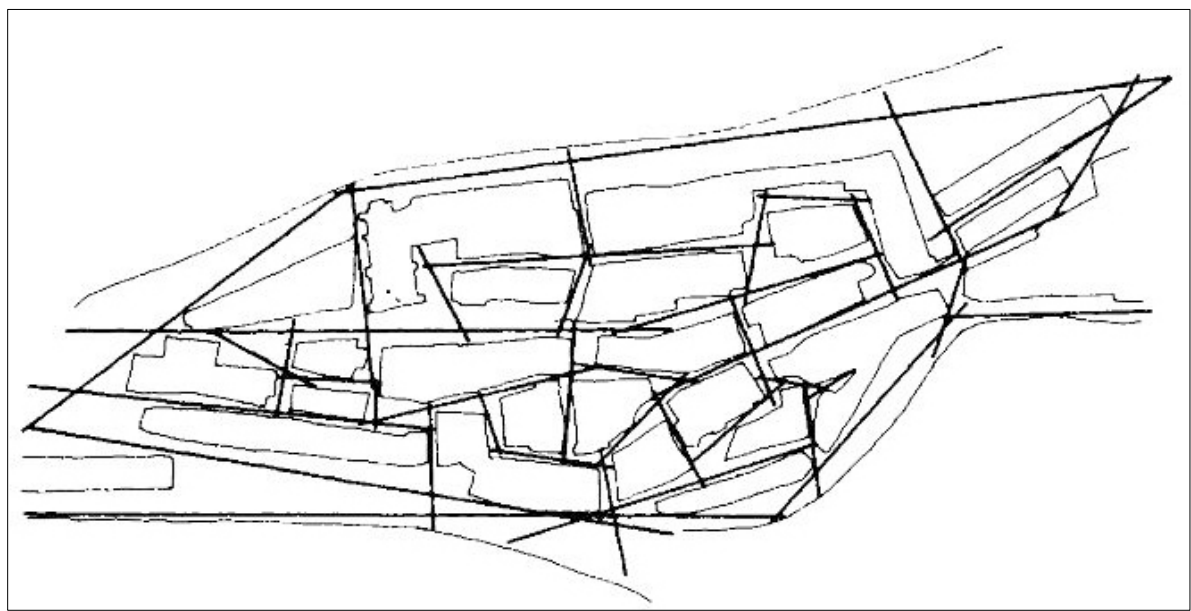

Space syntax analysis is based on measuring different characteristics of a street network reflecting the relative accessibility of various places in a city or region (Lebendiger \& Lerman, 2019). Space syntax can measure the spatial properties of a built environment in three ways: Metric distance, topological distance and geometric distance. Metric centrality refers to the central location in meters from one area to other areas. Topological centricity deals with the spatial configuration of the street and road network in terms of the number of direction changes. Geometric distance refers to the number of turns from one segment to the other. The more fragmented a street network is, the weaker the spatial features. This is about the degree of accessibility in terms of the least change of direction. Geometric centrality deals with changes in angular directions as you move from one place to another (Nes \& Yamu, 2017; Mohamed \& Stanek, 2020). These measurement types can be calculated in different radii from each street segment and again the radius can be defined as either the shortest, least-turn, or least-angle roads (Hillier \& Lida, 2005). The space syntax method can be applied at a wide variety of scales and levels in research on environments built at different levels, from residential to urban.

\section{Analytical Framework}

The study focuses on determining the level of accessibility and perceptibility at metric and topological levels within the Istiklal park and its accessibility limits. The methodology of the study consists of two basic stages, the first one determining and comparing topological and metric accessibility analyzes and the second one determining the perceptibility level.

Firstly, a convex area map was created by using the 2015 zoning plan as a basis within accessibility limits. By doing necessary markings on this map, an axle map as the basis of the spatial syntax method was obtained. In the next stage, an integration map used in topological and metric 
accessibility analysis and in determining perceptibility levels was developed by using the Depthmap 10 software.

Integration maps are important to describe how both vehicle and pedestrian movements work within the urban system, and to understand how often public spaces are used (Hillier, 2007). Areas with a high degree of integration attract more movement while areas with a low integration value attract less movement. This is an indication that the places with high integration value in the system are well connected, easily accessible and perceptible. Therefore, the perceptibility of the green areas located on the streets with high integrity value will be more than the green areas on the streets with low integrity value.

These analyzes were classified with the help of Arcgis 10.2 software and their percentages were calculated. Accessibility levels were divided into five sub-group as very low, low, medium, high and very high. In addition, the total number of population within the study area is given in table 2 . Total population was calculated by determining the population density per $\mathrm{m} 2$ of 4 neighborhoods and by multiplying it with square meters in the study area.

Table 2. Total population within the accessibility limits

\begin{tabular}{|l|l|l|l|l|}
\hline & $\begin{array}{l}\text { Total } \\
\text { Population of } \\
\text { Neighborhoods } \\
\text { (person) }\end{array}$ & $\begin{array}{l}\text { Area within } \\
\text { accessibility limits } \\
\text { oda) Name }\end{array}$ & $\begin{array}{l}\text { Total Area of the } \\
\text { Neighborhoods } \\
\text { (ha) }\end{array}$ & $\begin{array}{l}\text { Within } \\
\text { accessibility } \\
\text { limits } \\
\text { (person) }\end{array}$ \\
\hline 60. Yll & 14.766 & 5,53 & 46,88 & 1.736 \\
\hline Beyazlar & 9.808 & 9,21 & 74,01 & 1.221 \\
\hline İstiklal & 22.162 & 33,26 & 62,84 & 11.730 \\
\hline Konak & 19.425 & 0,13 & 61,74 & 41 \\
\hline Total & 66.161 & 49,09 & 245,47 & 14.727 \\
\hline
\end{tabular}

\section{RESULTS AND DISCUSSIONS}

\section{Metric Accessibility}

When the map showing the metric level of accessibility is examined (Figure 4), it is seen that there is a circular expansion towards the regions where the accessibility level is very low. The region with the highest accessibility level in the green area is the regions closest to the green area, while the regions with the lowest levels are the most remote. According to the table showing the rates of metric accessibility levels, the regions with the highest rates have the lowest access areas with 33.55\% (approximately 4941 people) and the areas with the lowest rates have the highest rates with $5.24 \%$ (approximately 771 people) (Table 3). 
Figure 4. Metric aspects of accessibility (areal distribution on the top, metric assessment on the bottom)
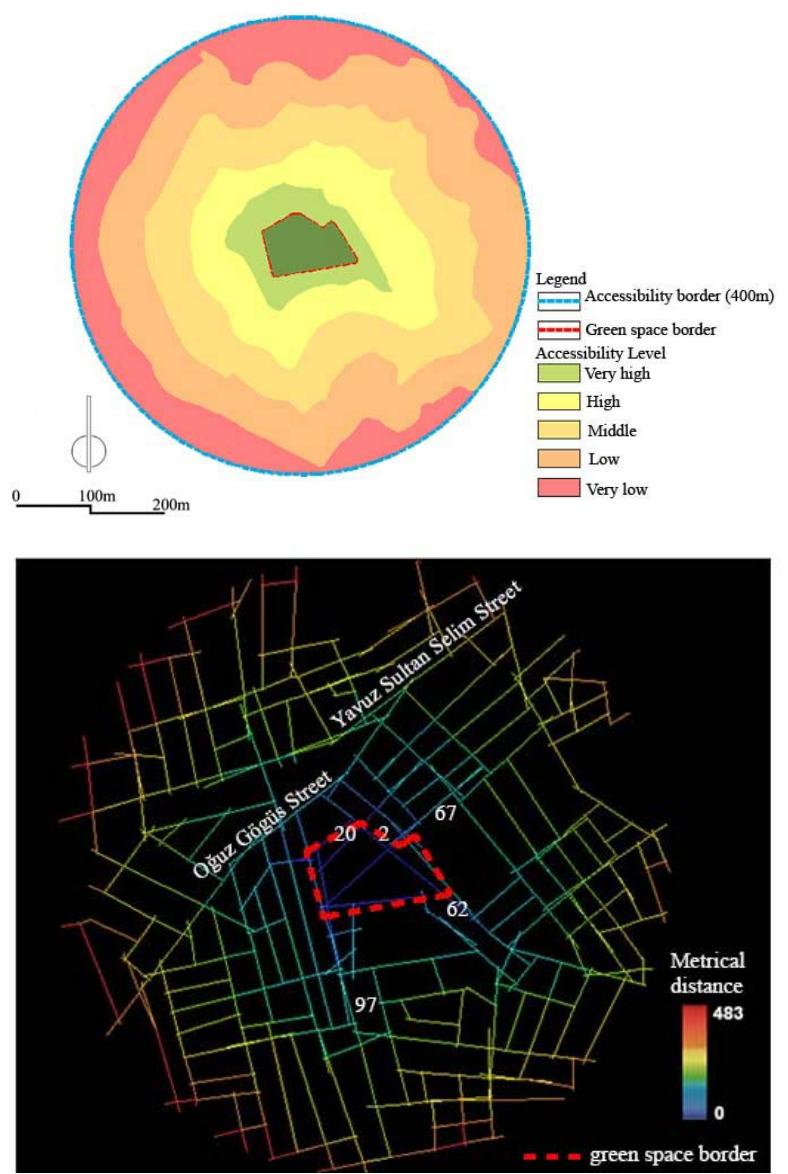

Table 3. Distribution of metric accessibility levels

\begin{tabular}{|l|l|l|l|}
\hline Accessibility Level & Area (ha) & Ratio (\%) & Population (person) \\
\hline Very high & 2,57 & 5,24 & 771 \\
\hline High & 7,52 & 15,32 & 2.256 \\
\hline Middle & 11,89 & 24,22 & 3.567 \\
\hline Low & 16,47 & 33,55 & 4.941 \\
\hline Very low & 10,64 & 21,67 & 3.192 \\
\hline Total & 49,09 & 100,00 & 14.727 \\
\hline
\end{tabular}

In general, when the accessibility of the green field in metric terms is evaluated, it has been determined that the areas with very high and high accessibility are $20.56 \%$ of the total area (approximately 3027 people), and the regions with low and very low accessibility are approximately $55.22 \%$ of the area (approximately 8133 people).

\section{Topological Accessibility}

When the map of topological accessibility levels were examined (Figure 5 ), it was observed that the areas where accessibility to the green area is very good are 2, 20, 62 and 67 streets and areas around 97th Street. Areas with very low access levels were observed in the northern part of the green areas. The main reason why the accessibility levels of the regions in the southern part of the study area is higher than the regions in the northern part is that 20th and 97th streets around the park are not stretched to the north of the area and that Yavuz Sultan Selim Street 
is blocking the access to green areas. The topological accessibility levels, their distribution and population numbers are given in Table 4.
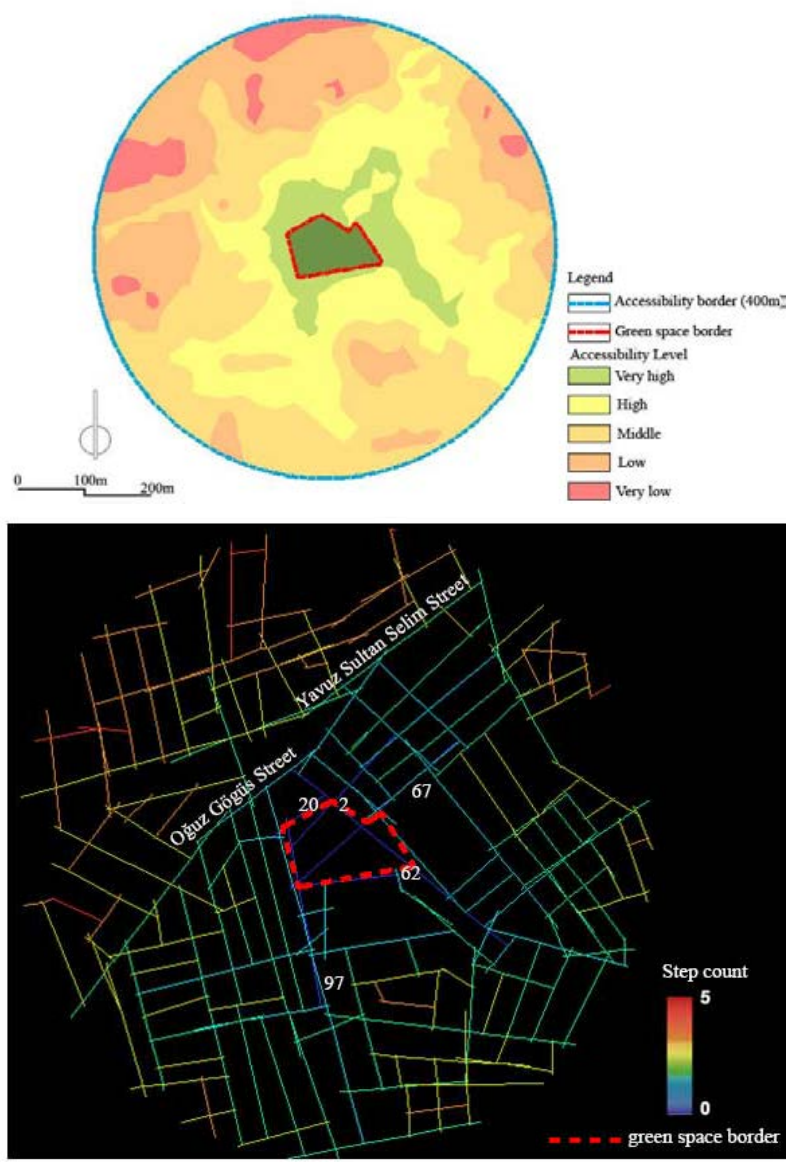

Figure 5. Topological accessibility levels (areal distribution on the top, topological depth on the bottom)

Table 4. Topological distribution of accessibility levels

\begin{tabular}{|l|l|l|l|}
\hline Accessibility Level & Area (ha) & Ratio (\%) & Population (person) \\
\hline Very high & 3,64 & 7,41 & 1,092 \\
\hline High & 12,96 & 26,40 & 3,888 \\
\hline Middle & 18,22 & 37,12 & 5,466 \\
\hline Low & 12,17 & 24,79 & 3,651 \\
\hline Very low & 2,1 & 4,28 & 645 \\
\hline Total & 49,09 & 100,00 & 14,727 \\
\hline
\end{tabular}

According to Table 3, 37.12 of those living within the accessibility limit had moderate access to green areas while $4.28 \%$ had very low level.

A general evaluation of topological accessibility shows that the areas with very high and high accessibility have a total area of $33.81 \%$ (approximately 4980 people), and regions with low and very low accessibility are approximately $29.07 \%$ of the area (approximately 4296 people).

\section{Comparison of Metric and Topological Accessibility Levels}

A comparison was made between both assessment results in order to determine the difference between metric and topological accessibility levels. This comparison shows that the areas with very high levels of 
accessibility are close to each other and the main difference is in areas with very low accessibility. The very low regions with a ratio of $4.38 \%$ in topological measurement have a ratio of $21.67 \%$ in metric measurements. This is due to the fact that the accessibility is shaped according to the distance from the green area in metric measurement. However, it is about the number of times that a person changes his direction to reach the green area rather than distance in topological measurement. In addition, in metrical accessibility assessments, the value of green areas with very high green space access is $5,24 \%$ of the total area while it is $7.41 \%$ in topological assessments. The reason for these low levels could be under-developed hierarchical road network in the study area. When the correlation graph of both measurements was examined (Figure 6), a moderate relationship was found between the measurements. The reason for this is that the areas with very high accessibility areas in both metric and topological aspects are close to each other.

Figure 6. Graph of correlation between topological and metric measurement

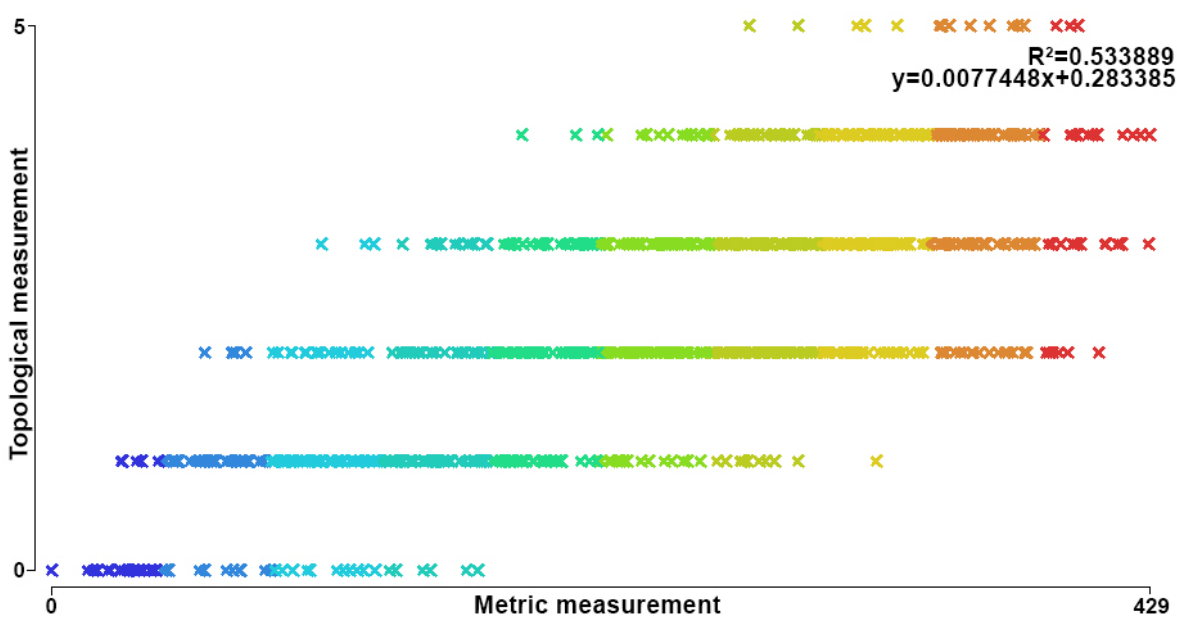

In general, there is a difference of approximately 13\% (1953 people) between regions with high accessibility values in both scales while this difference is approximately $26 \%$ (3837 people) between regions with low accessibility. Considering the regions with medium level accessibility between these two measurements, regions with moderate accessibility in metric measurement comprise approximately $24.22 \%$ of the total area (approximately 3567 people) while this ratio is approximately $37.12 \%$ (approximately 5466 people) on a topological scale.

\section{Determining the perceptibility Levels}

The integration map was used to determine perceptibility level of the green area. The integration map is an important indicator in describing the intensity of use in the system and in describing the frequency of space use. Therefore, the spaces located on the streets with high integration values will have high perceptibility. When the integration map constructed within the accessibility limit (Figure 7) was examined, 
the area where M. Oğuz Göğüs Street and Yavuz Sultan Selim Street intersect had the highest integration value with 2.12 while 12th Street and its close surroundings had the lowest value with 0.98 . The 20th, 2nd, 62nd and 92nd streets that limit the green area had integration values of $1.65,1.88,1.71,2.08$ respectively with an average of 1.81 .
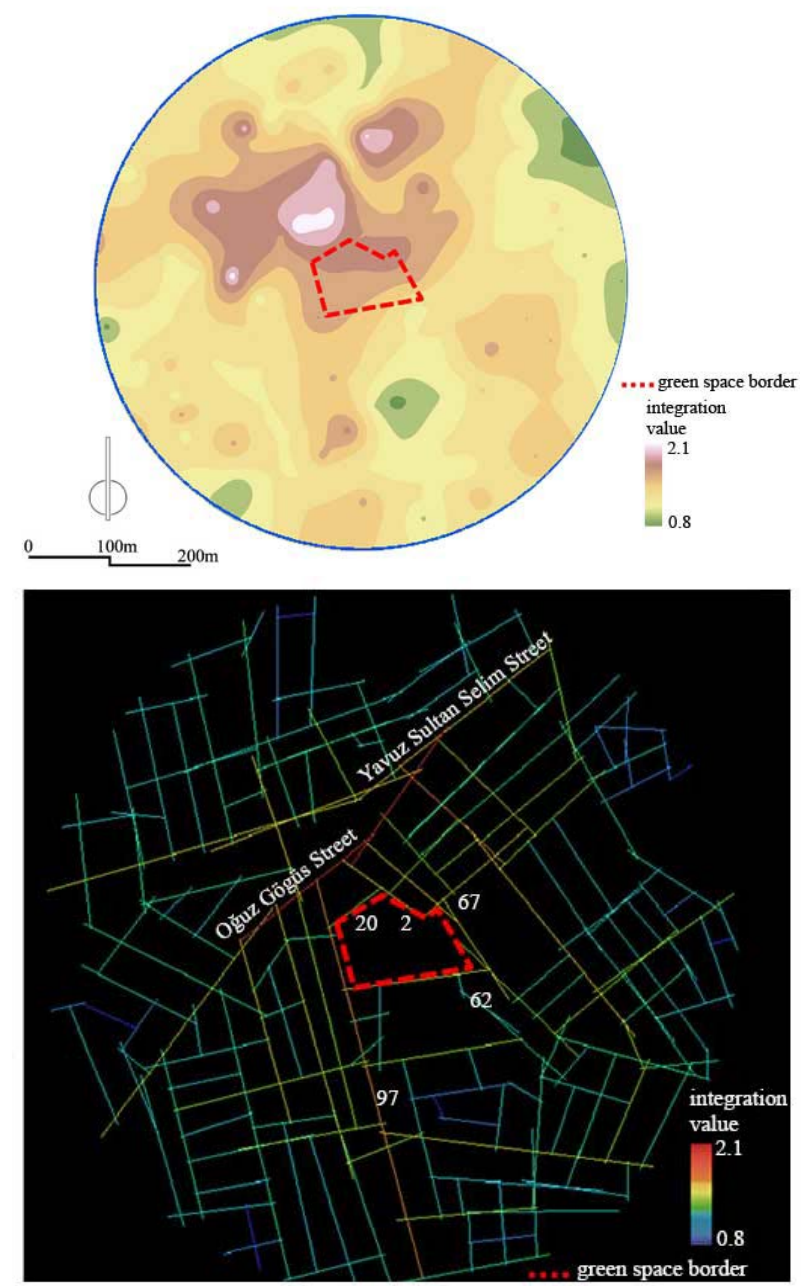

The fact that the selected green area is close to the region with a high value of integrity and the above average value of the street limiting this area requires a high perceptibility for this area. But the hierarchical road network within the study area is not sufficiently developed and the differences in the integration values between the regions constituting this area reduces the perceptibility of green areas.

The most important feature that differentiates this research from other studies is the use of spatial method in determining the accessibility and perceptibility levels. Many studies have evaluated green areas in terms of quality, size and possibilities (Daniels et al., 2018; de la Barrera et al., 2016; Ekkel \& de Vries, 2017; Fan et al., 2017; Van Herzele \& Wiedemann, 2003). In this study, the green areas were evaluated only in terms of their accessibility and perceptibility. While many studies conducted to determine accessibility values of green areas considered the metric distance (Ekkel \& de Vries, 2017; Fan et al., 2017; Gupta et al.,
Figure 7. Perceptibility map (areal distribution on the top, integrity map on the bottom) 
2016; La Rosa, 2014; Wright Wendel et al., 2012; Xiao et al., 2017), this study also takes the topological distance into account along with the metric distance. As the study reveals, the angular relationship of the streets plays a role in people's orientation towards the built environment. This is empirically supported by Conroy Dalton's research, which shows that angles affect people's choice of route at road intersections. He concluded that people tend to maintain linearity with minimal angular deviation in selected routes (Dalton, 2001). In addition, the method used in the study, its application for urban areas of different scales such as playgrounds, district, city and district parks, and comparison of urban areas of the same or different scales in terms of accessibility may be the subject of different studies.

\section{CONCLUSION}

This study evaluates the perceptibility and accessibility levels of Istiklal Park located in the Istiklal neighbourhood. The accessibility level was determined with topological and metric assessments and the results were compared. The integration map was utilized to determine the perceptibility level. As a result of this study, it was determined that;

$>$ There is a moderate relationship between metric measurement and topological measurement,

$>$ the spatial relationships between housing and green space are weak,

the perceptibility and accessibility of the selected green area is moderate.

This study moves from the hypothesis that the green areas are an important shared space for residents at the neighborhood level. Accordingly, space syntax method was utilized in order to provide more specific suggestions to the question of how neighborhoods should be designed in this direction. It is suggested that the green areas on the streets with high integrity value will have higher accessibility and perceptibility levels. But the streets with high integrity value will be overloaded with heavy traffic. Traffic is one of the most common obstacles in accessibility (Sallis et al., 2012). It should be kept in mind that especially busy streets will negatively affect the access of older people, children and disadvantaged groups. Therefore, it is very important to ensure that all segments of the society have access to these areas safely in the connection with the environment and to design multifunctional and safely accessible spaces in order to benefit from these areas. The results obtained from this study might contribute to the determination of the design-planning principles, sustainability of social areas, accessibility to urban areas and use of green spaces at the neighbourhood level. In addition, the study contributes to an understanding of how cities are built as an effect of social activities in spatial terms and how urban space functions as a driving force in its relation to social activities. 
The necessity of creating a liveable environment is to arrange the technical, social and cultural equipment-infrastructure needed by population and equal access to open and green spaces. Planners have a key role in providing communities with more equal access to healthier living environments. Urban and regional planners, landscape architects and implementers have a great responsibility in ensuring the ecological, psychological and economic benefits that urban green spaces provide to citizens. Urban planning is a complex and multidisciplinary process that requires more and more actors to communicate. Higher data requirements, different methods, accepted assumptions and limitations should be carefully considered by planners in planning processes. Indicators assessing accessibility to green spaces represent very useful tools for planners and provide solid foundations to local governments for developing policies that can create more livable and healthy urban environments.

\section{CONFLICT OF INTEREST}

There isn't any conflict of interest.

\section{FINANCIAL DISCLOSURE}

The authors declared that this study has received no financial support.

\section{ETHICS COMMITTEE APPROVAL}

Ethics committee approval was not required for this article.

\section{LEGAL PUBLIC/PRIVATE PERMISSIONS}

In this research, the necessary permissions were obtained from the relevant participants (individuals, institutions and organizations) during the survey, in-depth interview, focus group interview, observation or experiment.

\section{REFERENCES}

Afacan, Y. (2015). Yaşanabilir Kentsel Mekanlar İçin Erişilebilirliğin Önemi: Çukurambar Kentsel Dönüşüm Örneği. Dosya 36: Mekanlarda Erişilebilirlik, Kullanılabilirlik ve Yaşanabilirlik, 3, 20-25.

Alalouch, C., Aspinall, P., \& Smith, H. (2009). On locational preferences for privacy in hospital wards. Facilities, 27(3/4), 88-106. https://doi.org/10.1108/02632770910933125

Altunkasa, M. F. (2004). Adana'nın Kentsel Gelişim Süreci ve Yeşil Alanlar. Adana Kent Konseyi Çevre Çalışma Grubu Bireysel Raporu.

Asami, Y., Kubat, A. S., \& Istek, C. (2001). Characterization of the street networks in the traditional Turkish urban form. 21. https://doi.org/10.1068/b2718

Baran, P. K., Rodríguez, D. A., \& Khattak, A. J. (2008). Space Syntax and Walking in a New Urbanist and Suburban Neighbourhoods. Journal of Urban Design, 13(1), 5-28. https://doi.org/10.1080/13574800701803498 
Bolund, P., \& Hunhammar, S. (1999). Ecosystem services in urban areas. Ecological Economics, 29(2), 293-301. https://doi.org/10.1016/S09218009(99)00013-0

Dalton, N. (2001). Fractional Configurational Analysis And a solution to the Manhattan problem. Proceedings ., 14.

Daniels, B., Zaunbrecher, B. S., Paas, B., Ottermanns, R., Ziefle, M., \& RoßNickoll, M. (2018). Assessment of urban green space structures and their quality from a multidimensional perspective. Science of The Total Environment, 615 1364-1378. https://doi.org/10.1016/j.scitotenv.2017.09.167

de la Barrera, F., Reyes-Paecke, S., Harris, J., Bascuñán, D., \& Farías, J. M. (2016). People's perception influences on the use of green spaces in socio-economically differentiated neighborhoods. Urban Forestry \& Urban Greening, 20, 254-264. https://doi.org/10.1016/j.ufug.2016.0 9.007

Department of the Environment. (1994). Vital and viable town centres: Meeting the challenge, Department of the Environment-Publication Index / NBS. HMSO. https://www.thenbs.com/PublicationIndex/doc uments/details?Pub=DOE\&DocID=257855

Ekkel, E. D., \& de Vries, S. (2017). Nearby green space and human health: Evaluating accessibility metrics. Landscape and Urban Planning, 157, 214-220. https://doi.org/10.1016/j.landurbplan.2016.06.008

Fan, P., Xu, L., Yue, W., \& Chen, J. (2017). Accessibility of public urban green space in an urban periphery: The case of Shanghai. Landscape and Urban Planning, 165, 177-192. https://doi.org/10.1016/j.landu rbplan.2016.11.007

Fladd, S. G. (2017). Social syntax: An approach to spatial modification through the reworking of space syntax for archaeological applications. Journal of Anthropological Archaeology, 47, 127-138. https://doi.org/10.1016/j.jaa.2017.05.002

Francis, J. (2010). Associations between Public Space and Mental Health in New Residential Developments [PhD]. The University of Western Australia.

Gül, A., \& Küçük, V. (2001). Kentsel Açık-Yeşil Alanlar Ve Isparta Kenti Örneğinde İrdelenmesi. Süleyman Demirel Üniversitesi Orman Fakültesi Dergisi, $A(2), 27-48$.

Gupta, K., Roy, A., Luthra, K., Maithani, S., \& Mahavir. (2016). GIS based analysis for assessing the accessibility at hierarchical levels of urban green spaces. Urban Forestry \& Urban Greening, 18, 198-211. https://doi.org/10.1016/j.ufug.2016.06.005

Hanson, J., \& Hillier, B. (1987). The architecture of community: Some new proposals on the social consequences of architectural and planning decisions. Architecture et Comportement/Architecture and Behaviour, 3(3), 251-273.

Hillier, B, Penn, A., Hanson, J., Grajewski, T., \& Xu, J. (1993). Natural movement: Or, configuration and attraction in urban pedestrian movement. Environment and Planning B: Planning and Design, 20(1), 2966. https://doi.org/10.1068/b200029 
Hillier, Bill. (2001, May). A theory of the city as object: Or, how spatial laws mediate the social construction of urban space. Presented at: 3rd International Space Syntax Symposium, Atlanta, Georgia, USA. (2001). 3rd International Space Syntax Symposium, Atlanta, Georgia, USA. http://undertow.arch.gatech.edu/homepages/3sss/

Hillier, Bill. (2007). Space is the machine: A configurational theory of architecture. Space Syntax. http://discovery.ucl.ac.uk/3881/1/SITM.pdf

Hillier, Bill. (2008). Space and spatiality: What the built environment needs from social theory. Building Research \& Information, 36(3), 216230. https://doi.org/10.1080/09613210801928073

Hillier, Bill, Burdett, R., Peponis, J., \& Penn, A. (1987). Creating Life: Or, Does Architecture Determine Anything? Arch. 8 Comport./Arch. Behav., 3(3), 233-250.

Hillier, Bill, \& Hanson, J. (1984). The Social Logic of Space. Cambridge University Press. https://doi.org/10.1017/CB09780511597237

Hillier, Bill, \& Iida, S. (2005). Network and Psychological Effects in Urban Movement. In A. G. Cohn \& D. M. Mark (Eds.), Spatial Information Theory (Vol. 3693, pp. 475-490). Springer Berlin Heidelberg. https://doi.org/10.1007/11556114_30

Hillier, Bill, \& Lida, S. (2005). Network effects and psychological effects: A theory of urban movement. Network Effects and Psychological Effects: A Theory of Urban Movement, 1, 553-564.

Hillier, Bill, Turner, A., Yang, T., \& Park, H. T. (2007, June 12). Metric and Topo-Geometric Properties of Urban Street Networks: Metric and TopoGeometric Properties of Urban Street Networks. In Proceedings of the 6th International Space Syntax Symposium, Istanbul Turkey.

Karimi, K. (2012). A configurational approach to analytical urban design: 'Space syntax' methodology. URBAN DESIGN International, 17(4), 297318. https://doi.org/10.1057/udi.2012.19

Koohsari, M. J., Badland, H., Mavoa, S., Villanueva, K., Francis, J., Hooper, P., Owen, N., \& Giles-Corti, B. (2018). Are public open space attributes associated with walking and depression? Cities, 74, 119-125. https://doi.org/10.1016/j.cities.2017.11.011

Koohsari, M. J., Kaczynski, A. T., Giles-Corti, B., \& Karakiewicz, J. A. (2013). Effects of access to public open spaces on walking: Is proximity enough? Landscape and Urban Planning, 117, 92-99. https://doi.org/10.1016/j.landurbplan.2013.04.020

Koohsari, M. J., Mavoa, S., Villanueva, K., Sugiyama, T., Badland, H., Kaczynski, A. T., Owen, N., \& Giles-Corti, B. (2015). Public open space, physical activity, urban design and public health: Concepts, methods and research agenda. Health \& Place, 33, 75-82. https://doi.org/10.1016/j.healthplace.2015.02.009

La Rosa, D. (2014). Accessibility to greenspaces: GIS based indicators for sustainable planning in a dense urban context. Ecological Indicators, 42, 122-134. https://doi.org/10.1016/j.ecolind.2013.11.011

La Rosa, D., \& Privitera, R. (2013). Characterization of non-urbanized areas for land-use planning of agricultural and green infrastructure in 
The Evaluation of the Perceptibility and Accessibility: The Case of Gaziantep

urban contexts. Landscape and Urban Planning, 109(1), 94-106. https://doi.org/10.1016/j.landurbplan.2012.05.012

Lebendiger, Y., \& Lerman, Y. (2019). Applying space syntax for surface rapid transit planning. Transportation Research Part A: Policy and Practice, 128, 59-72. https://doi.org/10.1016/j.tra.2019.07.016

Leichenko, R. M., \& Solecki, W. D. (2008). Consumption, Inequity, and Environmental Justice: The Making of New Metropolitan Landscapes in Developing Countries. Society \& Natural Resources, 21(7), 611-624. https://doi.org/10.1080/08941920701744223

Mahdzar, S. S. S. (2008). Sociability Vs Accessibility Urban Street Life. [PhD, University College London]. /paper/Sociability-vs-accessibilityurban-street-life.-

Mahdzar/db18bff8dae457cf496b9148660068c24822be6f

Mohamed, A. A., \& Stanek, D. (2020). The influence of street network configuration on sexual harassment patterns in Cairo. Cities, 98, 102583. https://doi.org/10.1016/j.cities.2019.102583

Mustafa, F. A., \& Rafeeq, D. A. (2019). Assessment of elementary school buildings in Erbil city using space syntax analysis and school teachers' feedback. Alexandria Engineering Journal, 58(3), 1039-1052. https://doi.org/10.1016/j.aej.2019.09.007

Nes, A. van, \& Yamu, C. (2017). Space Syntax: A method to measure urban space related to social, economic and cognitive factors. In The Virtual and the Real in Planning and Urban Design: Perspectives, Practices and Applications (pp. 136-150). Routledge.

Nicholls, S. (2001). Measuring the accessibility and equity of public parks: A case study using GIS. Managing Leisure, 6(4), 201-219. https://doi.org/10.1080/13606710110084651

Önder, S., \& Polat, A. T. (2012). Kentsel Açık-Yeşil Alanların Kent Yaşamındaki Yeri Ve Önemi. Kentsel Peyzaj Alanlarının Oluşumu ve Bakım Esasları Semineri, 73-96.

Özbil, A., Peponis, J., \& Stone, B. (2011). Understanding the link between street connectivity, land use and pedestrian flows. URBAN DESIGN International, 16(2), 125-141. https://doi.org/10.1057/udi.2011.2

Özer, Ö., \& Kubat, A. S. (2007). WALKING INITIATIVES: a quantitative movement analysis. Proceedings, 6th International Space Syntax Symposium, İstanbul.

Penn, A. (2003). Space Syntax And Spatial Cognition: Or Why the Axial Line? Environment and Behavior, 36(1), 30-65. https://doi.org/10.1177/0013916502238864

Sallis, J. F., Floyd, M. F., Rodríguez, D. A., \& Saelens, B. E. (2012). Role of Built Environments in Physical Activity, Obesity, and Cardiovascular Disease. Circulation, 125(5), 729-737. https://doi.org/10.1161/circula tionaha.110.969022

Sanesi, G., Lafortezza, R., Bonnes, M., \& Carrus, G. (2006). Comparison of two different approaches for assessing the psychological and social dimensions of green spaces. Urban Forestry \& Urban Greening, 5(3), 121-129. https://doi.org/10.1016/j.ufug.2006.06.001 
Stessens, P., Khan, A. Z., Huysmans, M., \& Canters, F. (2017). Analysing urban green space accessibility and quality: A GIS-based model as spatial decision support for urban ecosystem services in Brussels. Ecosystem Services, 28, 328-340. https://doi.org/10.1016/j.ecoser.2017.10.016

Topçu, M. (2019). Morphological Structures of Historical Turkish Cities. Iconarp International J. of Architecture and Planning, 7(Special Issue "Urban Morphology"), 212-229. https://doi.org/10.15320/ICONARP. 2019.86

TÜİK. (2018). Türkiye İstatistik Kurumu. http://www.tuik.gov.tr/UstMe nu.do?metod=temelist

Ünlü, T. (2018). Mekânın Biçimlendirilmesi ve Kentsel Morfoloji. İn [DeğişKent] Değişen Kent, Mekan ve Biçim, Türkiye Kentsel Morfoloji Araştırma Ağı II. Kentsel Morfoloji Sempozyumu (pp. 59-70).

Van Herzele, A., \& Wiedemann, T. (2003). A monitoring tool for the provision of accessible and attractive urban green spaces. Landscape and Urban Planning, 63(2), 109-126. https://doi.org/10.1016/S01692046(02)00192-5

Ward Thompson, C. (2011). Linking landscape and health: The recurring theme. Landscape and Urban Planning, 99(3-4), 187-195. https://doi.org/10.1016/j.landurbplan.2010.10.006

Wright Wendel, H. E., Zarger, R. K., \& Mihelcic, J. R. (2012). Accessibility and usability: Green space preferences, perceptions, and barriers in a rapidly urbanizing city in Latin America. Landscape and Urban Planning, 107(3), 272-282. https://doi.org/10.1016/j.landurbplan.2012.06.003

Xiao, Y., Wang, Z., Li, Z., \& Tang, Z. (2017). An assessment of urban park access in Shanghai - Implications for the social equity in urban China. Landscape and Urban Planning, 157, 383-393. https://doi.org/10.1016/j.landurbplan.2016.08.007

\section{Resume}

Ahmet Salih Gunaydin is an Assistant Professor in the Faculty of Fine Arts and Design at Inonu University, Malatya. After he completed his master's degree at Ankara University in 2014, received his Ph.D. in Landscape Architecture from Cukurova University in 2018. The area of interest focuses on spatial configuration, conservation development in historical environment, urban design, and space syntax.

Murat Yücekaya is working as an Assistant Professor at the Faculty of Engineering and Architecture, Department of Landscape Architecture at Nevşehir Haci Bektaş Veli University. He received his Ph.D. in Landscape Architecture from Cukurova University in 2017. His main research subjects are climate balanced urban design, urban heat island, microclimate simulations, and sustainable design. 